\title{
Alloying Behavior of Quaternary Elements in $\mathrm{Ni}_{3}(\mathrm{Si}, \mathrm{Ti})$
}

\author{
H. Sugimura, Y. Kaneno and T. Takasugi* \\ Department of Materials Science, Osaka Prefecture University, 1-1 Gakuen-cho, Naka-ku, Sakai 599-8531, Japan
}

\begin{abstract}
The thermodynamic treatment, which is based on the difference of heat of formation among three extreme cases for the substitution of a quaternary element $\mathrm{X}$, was applied to predict the substitution behavior of quaternary elements in $\mathrm{Ni}_{3}(\mathrm{Si}, \mathrm{Ti})$. The heat of formation of a hypothetical ternary compound $\mathrm{Ni}_{6} \mathrm{SiTi}$ in which $\mathrm{X}$ elements substitute for relevant sites was calculated by using a geometric model based on an extended Miedema's theory. According to the prediction, $\mathrm{Cr}$ and W (6), Mn and Re (7), Fe and Os (8), Co and $\operatorname{Ir}(9), \mathrm{Pt}(10)$, and Cu and $\mathrm{Au}(11)$ substitute for $\mathrm{Ni}$ atoms. Ge (14) substitutes for $\mathrm{Si}$ atoms. $\mathrm{Zr}$ and $\mathrm{Hf}$ (4), $\mathrm{V}, \mathrm{Nb}$, and $\mathrm{Ta}$ (5), $\mathrm{Mo}$ (6), and $\mathrm{Al}$ (13) substitute for $\mathrm{Ti}$ atoms. Ga (13) substitutes for $\mathrm{Si}$ or $\mathrm{Ti}$ atom. The prediction for Ta is consistent with the reported experimental result. Also, the solubility limits of quaternary elements for the Ti site in $\mathrm{Ni}_{3}(\mathrm{Si}, \mathrm{Ti})$ are ranked in the sequence of $\mathrm{Ta}>\mathrm{Nb}>\mathrm{V}>\mathrm{Hf}>\mathrm{Zr}$, and correlated with the size misfit parameter between $\mathrm{Ti}$ and the quaternary element $\mathrm{X}$, and the difference in heats of formation between $\mathrm{Ni}_{6} \mathrm{SiTi}_{\text {and }} \mathrm{Ni}_{6} \mathrm{SiX}_{\mathrm{X}}$. [doi:10.2320/matertrans.M2011095]
\end{abstract}

(Received March 29, 2011; Accepted May 31, 2011; Published July 13, 2011)

Keywords: site occupancy, $\mathrm{Ni}_{3}(\mathrm{Si}, \mathrm{Ti}), \mathrm{LI}_{2}$ structure, $\mathrm{A}_{6} \mathrm{BC}$ structure, thermodynamic model, alloying behavior

\section{Introduction}

The substitution behavior of ternary elements in $\mathrm{Ni}_{3} \mathrm{Al}$, $\mathrm{Ni}_{3} \mathrm{Ga}, \mathrm{Ni}_{3} \mathrm{Si}$, and $\mathrm{Ni}_{3} \mathrm{Ge}$ with $\mathrm{L}_{2}$ structure that are categorized to geometrically close-packed (GCP) compounds has been investigated and reviewed by Ochiai et al. ${ }^{1)}$ The thermodynamic Bragg-Williams model involving the nearest neighbor interactions, i.e., the change in total bonding energy of the host compound by a small addition of ternary solute at stoichiometry, has been applied to these $\mathrm{L}_{2}$ compounds. The bond energy of each pair was derived from the heat of compound formation by Miedema's formula. ${ }^{2,3)}$ The agreement for the substitution behavior of ternary elements between the prediction and the experimental results was found to be excellent. Later, the same treatment has been conducted on other GCP structures, that is, on $\mathrm{Co}_{3} \mathrm{Ti}$ with $\mathrm{L}_{2}$ structure, ${ }^{4)} \mathrm{Ni}_{3} \mathrm{Nb}, \mathrm{Ni}_{3} \mathrm{Ta}$, and $\mathrm{Ni}_{3} \mathrm{Mo}$ with $\mathrm{D}_{\mathrm{a}}$ structure, $\mathrm{Ni}_{3} \mathrm{~V}$ with $\mathrm{DO}_{22}$ structure, and $\mathrm{Ni}_{3} \mathrm{Ti}$ with $\mathrm{DO}_{24}$ structure by the present author's group ${ }^{4-8)}$ and was shown to be successful in predicting the substitution behavior of ternary elements. Regarding the solubility limits of ternary elements $\mathrm{X}$ in $\mathrm{Ni}_{3} \mathrm{Al}$ and $\mathrm{Ni}_{3} \mathrm{Ga}$ with $\mathrm{L}_{2}$ structure, a successful prediction was found by Ochiai et al. ${ }^{1)}$ based on the two-dimensional map, in which the difference in heats of formation between $\mathrm{Ni}_{3} \mathrm{Al}$ (or $\mathrm{Ni}_{3} \mathrm{Ga}$ ) and $\mathrm{Ni}_{3} \mathrm{X}$, and the changing rate of lattice parameter by alloying of $\mathrm{Ni}_{3} \mathrm{Al}$ (or $\mathrm{Ni}_{3} \mathrm{Ga}$ ) were taken into calculation as two parameters.

$\mathrm{Ni}_{3}(\mathrm{Si}, \mathrm{Ti})$ with $\mathrm{Ll}_{2}$ structure, which has been developed by adding $\mathrm{Ti}$ to $\mathrm{Ni}_{3} \mathrm{Si}_{1}{ }^{10)}$ possesses many attractive properties as high-temperature structural materials. For example, $\mathrm{Ni}_{3}(\mathrm{Si}, \mathrm{Ti})$ whose $\mathrm{Si}$ and $\mathrm{Ti}$ contents are comprised of an almost equal atomic composition has been reported to show a positive temperature dependence of yield strength and exhibit higher strength and peak temperature in the strength versus temperature curve than binary $\mathrm{Ni}_{3} \mathrm{Si}^{1{ }^{10)}}$ Also, relatively low density $\left(<8 \mathrm{gr} / \mathrm{mm}^{3}\right)$ and good corrosion resistance of $\mathrm{Ni}_{3}(\mathrm{Si}, \mathrm{Ti})$ are favorable properties for high-temperature structural materials. ${ }^{11)}$ In addition, high tensile ductility

*Corresponding author, E-mail: takasugi@mtr.osakafu-u.ac.jp over a wide range of temperatures owing to the prevention of the propensity for an intergranular fracture is a notable feature of $\mathrm{Ni}_{3}(\mathrm{Si}, \mathrm{Ti}){ }^{10)}$ Such high tensile ductility of $\mathrm{Ni}_{3}(\mathrm{Si}, \mathrm{Ti})$ is noteworthy because most intermetallic alloys have very limited ductility, particularly at low temperatures. Recently, $\mathrm{Ni}_{3}(\mathrm{Si}, \mathrm{Ti})$ that was thermo-mechanically fabricated from conventional polycrystalline ingots exhibited an extremely high tensile strength and yield strength (more than $2 \mathrm{GPa}$ ) accompanied with high fracture strain at a wide range of temperatures and was superior to the commercial nickel alloys and stainless steels at temperatures below $873 \mathrm{~K}^{12}$ ) However, the tensile strength and the elongation of the thermo-mechanically processed $\mathrm{Ni}_{3}(\mathrm{Si}, \mathrm{Ti})$ were found to rapidly decrease at temperatures beyond $873 \mathrm{~K}$. Therefore, the improvement of the high-temperature mechanical properties is considerably desired, e.g., by adding quaternary elements to $\mathrm{Ni}_{3}(\mathrm{Si}, \mathrm{Ti})$. It has been actually reported by the present author's group that the mechanical and chemical properties of $\mathrm{Ni}_{3}(\mathrm{Si}, \mathrm{Ti})$ were improved by the addition of some quaternary elements. ${ }^{13-17)}$ Therefore, to predict the substitution behavior as well as the solubility limits of quaternary elements in $\mathrm{Ni}_{3}(\mathrm{Si}, \mathrm{Ti})$ is a critical issue to further improve mechanical and chemical properties of $\mathrm{Ni}_{3}(\mathrm{Si}, \mathrm{Ti})$.

In an early part of this paper, we predicted the substitution behavior of quaternary elements $\mathrm{X}$ in $\mathrm{Ni}_{3}(\mathrm{Si}, \mathrm{Ti})$ by the thermodynamic model. In the calculation, $\mathrm{Ni}_{3}(\mathrm{Si}, \mathrm{Ti})$ with $\mathrm{L}_{2}$ structure was hypothesized as ternary compound $\mathrm{Ni}_{6} \mathrm{SiTi}$ with high ordered structure derived from $\mathrm{L}_{2}$ structure, i.e., $\mathrm{Pt}_{6} \mathrm{CuMn}$ structure type. In a latter part of this paper, we predicted the solubility limits of quaternary elements $\mathrm{X}$ based on a two-dimensional map on which the difference in heats of formation between $\mathrm{Ni}_{6} \mathrm{SiTi}$ and $\mathrm{Ni}_{6} \mathrm{SiX}$ (or $\mathrm{Ni}_{6} \mathrm{XTi}$ ), and the atomic size difference between $\mathrm{Ti}$ and the quaternary element $\mathrm{X}$, and the agreement between the experiment and the prediction was discussed.

\section{The Substitution Behavior of Quaternary Elements}

This section is devoted to showing whether a simple thermodynamic treatment will serve to account for the 
(a)

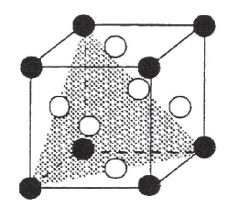

(b)

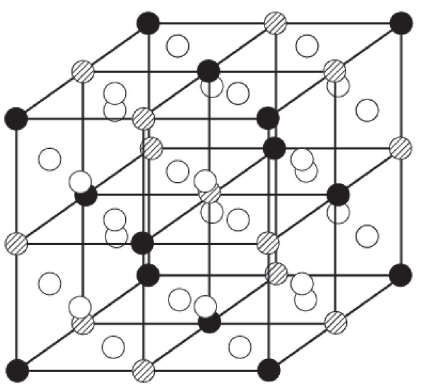

Fig. 1 Crystal structures of (a) $\mathrm{Ni}_{3}(\mathrm{Si}, \mathrm{Ti})$ with $\mathrm{L1}_{2}$ structure and (b) $\mathrm{Ni}_{6} \mathrm{SiTi}$ with $\mathrm{Pt}_{6} \mathrm{CuMn}$ structure. In (a), open circles correspond to $\mathrm{Ni}$ atoms and full circles correspond to $\mathrm{Si}$ or $\mathrm{Ti}$ atoms. In (b), open circles correspond to $\mathrm{Ni}$ atoms, full circles correspond to $\mathrm{Si}$ atoms, shaded circles correspond to $\mathrm{Ti}$ atoms.

substitution behavior of quaternary elements $\mathrm{X}$ in $\mathrm{Ni}_{3}(\mathrm{Si}, \mathrm{Ti})$, based on the Bragg-Williams model of nearest neighbor interactions. In the $\mathrm{Ni}_{3} \mathrm{M}$-type compounds with $\mathrm{L} 1_{2}$ structure showing the anomalous temperature dependence of strength caused by the cross-slip of dislocations that are stemming from the anisotropy in the antiphase boundary (APB) energy between (111) and (001) planes, the relevant APB energies calculated on an assumption that only the nearest neighbor atomic arrangements were taken into was shown to be consistent with the experimentally determined APB energies. ${ }^{18)}$ Therefore, the second and further distant neighbor interaction energies are likely to be negligible for the prediction of the substitution behavior of quaternary elements $\mathrm{X}$ in $\mathrm{Ni}_{3}(\mathrm{Si}, \mathrm{Ti})$ which similarly exhibits the anomalous temperature dependence of strength. ${ }^{19)}$

The $\mathrm{L1}_{2}$ structure $\left(\mathrm{Cu}_{3} \mathrm{Au}\right.$ structure type, $\mathrm{cP} 4$, space group $\mathrm{Pm} \overline{3} \mathrm{~m}$ ) has two crystallographic sites: in the case of $\mathrm{Ni}_{3}(\mathrm{Si}, \mathrm{Ti})$, one site is available for $\mathrm{Ni}$ atoms at the face centers and the other site for $\mathrm{Si}$ or $\mathrm{Ti}$ atoms at cube corners as shown in Fig. 1(a). To apply the thermodynamic calculation to the substitution behavior of the quaternary elements $\mathrm{X}$ in $\mathrm{Ni}_{3}(\mathrm{Si}, \mathrm{Ti})$, a hypothesis is required. The $\mathrm{Ni}_{3}(\mathrm{Si}, \mathrm{Ti})$ binary compound, in which $\mathrm{Si}$ and $\mathrm{Ti}$ atoms randomly occupies the cube corners should be assumed to be the $\mathrm{Ni}_{6} \mathrm{SiTi}$ ternary compound $\left(\mathrm{Pt}_{6} \mathrm{CuMn}\right.$ structure type, cP32, space group $\mathrm{Fm} \overline{3} \mathrm{~m}$ ), in which $\mathrm{Si}$ and $\mathrm{Ti}$ atoms form ordered structures called as $\mathrm{NaCl}$ structure in their sub-lattice sites, i.e., at the cube corner sites as shown in Fig. 1(b). As the ternary compounds with such a high ordered structure that are expressed by $\mathrm{A}_{6} \mathrm{BC}$ and derived from $\mathrm{A}_{3} \mathrm{~B}$-type $\mathrm{L}_{2}$ structure, $\mathrm{Pt}_{6} \mathrm{CuMn}^{20)}$ have been recently found to actually exist. Also, it is suggested that such an ordering in the cub corner sites is not unreasonable to be formed when B and C atoms are attractive each other. Since $\mathrm{Si}$ and $\mathrm{Ti}$ atoms are attractive each other from the view point of the periodic table, both atoms tend to preferentially interact with the different atoms in the neighboring sites constructing their sub-lattice.

The thermodynamic treatment is based on the difference of heat of formation among three extreme cases for the substitution of a quaternary element $X$. The heats of formation of ternary compounds are calculated by using a geometric model based on extended Miedema's theories where specific crystal structures are not taken into the

calculation in contrast to the first principle calculation (or $a b$ initio calculation). ${ }^{21-23)}$ According to the geometric model, the heat of formation for a ternary compound can be expressed as follows:

$$
\begin{aligned}
\Delta H_{\mathrm{ABC}}= & \left(x_{\mathrm{A}} x_{\mathrm{B}} / y_{\mathrm{AB}}^{\mathrm{A}} y_{\mathrm{AB}}^{\mathrm{B}}\right) \Delta H_{\mathrm{AB}}\left(y_{\mathrm{AB}}^{\mathrm{A}}, y_{\mathrm{AB}}^{\mathrm{B}}\right) \\
& +\left(x_{\mathrm{A}} x_{\mathrm{C}} / y_{\mathrm{AC}}^{\mathrm{A}} y_{\mathrm{AC}}^{\mathrm{C}}\right) \Delta H_{\mathrm{AC}}\left(y_{\mathrm{AC}}^{\mathrm{A}}, y_{\mathrm{AC}}^{\mathrm{C}}\right) \\
& +\left(x_{\mathrm{B}} x_{\mathrm{C}} / y_{\mathrm{BC}}^{\mathrm{B}} y_{\mathrm{BC}}^{\mathrm{C}}\right) \Delta H_{\mathrm{BC}}\left(y_{\mathrm{BC}}^{\mathrm{B}}, y_{\mathrm{BC}}^{\mathrm{C}}\right)
\end{aligned}
$$

Here, $\Delta H_{i j}(i=\mathrm{A}$ or $\mathrm{B} ; j=\mathrm{B}$ or $\mathrm{C}$ ), which is the heat of formation in the $i-j$ binary system, is calculated at the composition of $y_{i j}^{i}$ and $y_{j i}^{i}$ for $i$ and $j$ components, respectively. $x_{\mathrm{A}}, x_{\mathrm{B}}$, and $x_{\mathrm{C}}$ are the mole fractions of $\mathrm{A}, \mathrm{B}$, and $\mathrm{C}$ in the A-B-C ternary system, respectively. To obtain the validity for the heats of the formation calculated in the present study (i.e., by extended Miedema's theories), the heats of formation for ternary compounds reported in $\mathrm{Ni}-\mathrm{Si}$ $\mathrm{Ti}, \mathrm{X}-\mathrm{Si}-\mathrm{Ti}$, and Ni-Si-X alloy systems were calculated and compared with the literature values. ${ }^{24-27)}$ It is noted that a majority of literature's data were not obtained by experimental works but by ' $a b$ initio' calculation, as shown in Table 1. It is demonstrated from this table that the present calculations are not so much different from those reported from the literatures, therefore indicating that the present calculation is reliable enough to predict the substitution of a quaternary element $\mathrm{X}$ in $\mathrm{Ni}_{3}\left(\mathrm{Si}\right.$, Ti), i.e., $\mathrm{Ni}_{6} \mathrm{SiTi}$.

Comparison will be made on the difference of heats of formation among three extreme cases for the substitution of a quaternary element $\mathrm{X}$. One case is that $\mathrm{X}$ atoms substitute for $\mathrm{Ni}$ atoms on the $\mathrm{Ni}$ site and $\Delta H\left(\mathrm{X}_{6} \mathrm{SiTi}\right)$ is calculated, another case is that $\mathrm{X}$ atoms substitute for $\mathrm{Si}$ atoms on the Si site and $\Delta H\left(\mathrm{Ni}_{6} \mathrm{XTi}\right)$ is calculated, and the other case is that $\mathrm{X}$ atoms substitute for $\mathrm{Ti}$ atoms on the $\mathrm{Ti}$ site and $\Delta H$ $\left(\mathrm{Ni}_{6} \mathrm{SiX}\right)$ is calculated. The substitution behavior of a quaternary element $\mathrm{X}$ can be determined by the following expression $^{1)}$

$$
\Delta H\left(\mathrm{X}_{6} \mathrm{SiTi}\right) \lessgtr \Delta H\left(\mathrm{Ni}_{6} \mathrm{XTi}\right) \lessgtr \Delta H\left(\mathrm{Ni}_{6} \mathrm{SiX}\right) .
$$

If $\Delta H\left(\mathrm{X}_{6} \mathrm{SiTi}\right)$ is negatively larger than $\Delta H\left(\mathrm{Ni}_{6} \mathrm{XTi}\right)$ and $\Delta H\left(\mathrm{Ni}_{6} \mathrm{SiX}\right), \mathrm{X}$ atoms mostly substitute for $\mathrm{Ni}$ atoms. If $\Delta H\left(\mathrm{Ni}_{6} \mathrm{XTi}\right)$ is negatively larger than $\Delta H\left(\mathrm{X}_{6} \mathrm{SiTi}\right)$ and $\Delta H\left(\mathrm{Ni}_{6} \mathrm{SiX}\right), \mathrm{X}$ atoms mostly substitute for $\mathrm{Si}$ atoms. If $\Delta H\left(\mathrm{Ni}_{6} \mathrm{SiX}\right)$ is negatively larger than $\Delta H\left(\mathrm{X}_{6} \mathrm{SiTi}\right)$ and $\Delta H$ $\left(\mathrm{Ni}_{6} \mathrm{XTi}\right), \mathrm{X}$ atoms mostly substitute for $\mathrm{Ti}$ atoms. The calculated results are summarized in Fig. 2 and Table 2, and the substitution behavior of quaternary elements $\mathrm{X}$ was determined. The quaternary element prefers to occupy the site with the largest negative heat of formation. Consequently, Cr and W (6), Mn and Re (7), Fe and Os (8), Co and Ir (9), $\mathrm{Pt}(10)$, and $\mathrm{Cu}$ and $\mathrm{Au}$ (11) are attracted to $\mathrm{Si}$ and $\mathrm{Ti}$ atoms stronger than $\mathrm{Ni}$ atoms. In this case, it is predicted that these elements substitute for $\mathrm{Ni}$ atoms. Ge (14) is attracted to $\mathrm{Ni}$ and $\mathrm{Ti}$ atoms stronger than $\mathrm{Si}$ atoms. In this case, it is predicted that the element substitutes for $\mathrm{Si}$ atoms. $\mathrm{Zr}$ and $\mathrm{Hf}$ (4), V, Nb, and Ta (5), Mo (6), and $\mathrm{Al}$ (13) are attracted to $\mathrm{Ni}$ and $\mathrm{Si}$ atoms stronger than $\mathrm{Ti}$ atoms. In this case, it is predicted that these elements substitute for $\mathrm{Ti}$ atoms. $\mathrm{Ga}(13)$ is attracted to $\mathrm{Ni}$ atoms stronger than $\mathrm{Si}$ and $\mathrm{Ti}$ atoms. In this case, it is predicted that the element substitutes for Si or Ti atom. Thus, the substitution behavior 
Table 1 Comparisons of heats of formation for ternary compounds reported in Ni-Si-Ti, X-Si-Ti, and Ni-Si-X alloy systems between the present calculation and the literatures.

\begin{tabular}{|c|c|c|c|}
\hline \multirow{2}{*}{ System } & \multirow{2}{*}{ Phase } & \multicolumn{2}{|c|}{$\Delta H, \mathrm{~kJ} / \mathrm{mole}$} \\
\hline & & The literatures [Ref.] & The present calculation (extended Miedema) \\
\hline \multirow{5}{*}{ Ni-Si-Ti } & $\mathrm{Ni}_{16} \mathrm{Si}_{7} \mathrm{Ti}_{6}$ & -54.67 (ab initio) 24$)$ & -62.05 \\
\hline & \multirow{2}{*}{$\mathrm{Ni}_{3} \mathrm{SiTi}_{2}$} & $-59.20(a b$ initio $) 24)$ & \multirow{2}{*}{-62.88} \\
\hline & & $-62.00(a b$ initio $) 26)$ & \\
\hline & NiSiTi & $-81.86(a b$ initio $) 24)$ & -72.51 \\
\hline & $\mathrm{Ni}_{17} \mathrm{Si}_{7} \mathrm{Ti}_{6}$ & $-68.36,-68.65$ (ab initio) 25$)$ & -60.60 \\
\hline \multirow{5}{*}{$\mathrm{X}-\mathrm{Si}-\mathrm{Ti}$} & $\mathrm{Cr}_{3} \mathrm{SiTi}_{2}$ & -36.3 (ab initio) 26$)$ & -35.97 \\
\hline & $\mathrm{Mn}_{3} \mathrm{SiTi}_{2}$ & -54.5 (ab initio) 26$)$ & -40.78 \\
\hline & \multirow{2}{*}{$\mathrm{Fe}_{3} \mathrm{SiTi}_{2}$} & $-52.4($ ab initio $) 26)$ & \multirow{2}{*}{-45.67} \\
\hline & & $-55.9 \pm 1.6$ (calorimetry) 26$)$ & \\
\hline & $\mathrm{Co}_{3} \mathrm{SiTi}_{2}$ & $-58.6($ ab initio $) 26)$ & -57.01 \\
\hline \multirow{6}{*}{ Ni-Si-X } & $\mathrm{Ni}_{16} \mathrm{Si}_{7} \mathrm{Zr}_{6}$ & $-74.78(a b$ initio $) 25)$ & -75.05 \\
\hline & $\mathrm{Ni}_{17} \mathrm{Si}_{7} \mathrm{Zr}_{6}$ & $-72.76(a b$ initio $) 25)$ & -73.29 \\
\hline & $\mathrm{Ni}_{16} \mathrm{Si}_{7} \mathrm{Hf}_{6}$ & $-78.59,-77.14(a b$ initio $) 25)$ & -69.87 \\
\hline & \multirow{3}{*}{$\mathrm{Ni}_{2} \mathrm{SiAl}$} & $-50.43 \pm 2.0$ (calorimetry) 27 ) & \multirow{3}{*}{-49.85} \\
\hline & & -56.36 (first-principles method) 27) & \\
\hline & & -55.00 (calphad) 23) & \\
\hline
\end{tabular}

Table 2 The substitution behavior of quaternary elements in $\mathrm{Ni}_{3}(\mathrm{Si}, \mathrm{Ti})$. Three types of heats of formation, $\Delta H\left(\mathrm{X}_{6} \mathrm{SiTi}\right), \Delta H\left(\mathrm{Ni}{ }_{6} \mathrm{XTi}\right)$, and $\Delta H\left(\mathrm{Ni}_{6} \mathrm{SiX}\right)$, are calculated and listed in the column.

\begin{tabular}{|c|c|c|c|c|c|c|}
\hline $\begin{array}{c}\text { Electronic nature } \\
\text { (Group number } \\
\text { in the periodic table) }\end{array}$ & $\begin{array}{l}\text { quaternary } \\
\text { element } \\
\text { (X) }\end{array}$ & $\begin{array}{c}\Delta H\left(\mathrm{X}_{6} \mathrm{SiTi}\right) \\
(\mathrm{kJ} / \mathrm{mol})\end{array}$ & $\begin{array}{c}\Delta H\left(\mathrm{Ni}_{6} \mathrm{XTi}\right) \\
(\mathrm{kJ} / \mathrm{mol})\end{array}$ & $\begin{array}{c}\Delta H\left(\mathrm{Ni}_{6} \mathrm{SiX}\right) \\
(\mathrm{kJ} / \mathrm{mol})\end{array}$ & Site preference & $\begin{array}{c}\text { Substitution } \\
\text { site }\end{array}$ \\
\hline \multirow{2}{*}{4} & $\mathrm{Zr}$ & -31.57 & -35.37 & -44.34 & $\mathrm{Ni}<\mathrm{Si}<\mathrm{Ti}$ & $\mathrm{Ti}$ \\
\hline & Hf & -28.85 & -33.07 & -41.45 & $\mathrm{Ni}<\mathrm{Si}<\mathrm{Ti}$ & $\mathrm{Ti}$ \\
\hline \multirow{3}{*}{5} & $\mathrm{~V}$ & -23.15 & -22.60 & -26.76 & $\mathrm{Si}<\mathrm{Ni}<\mathrm{Ti}$ & $\mathrm{Ti}$ \\
\hline & $\mathrm{Nb}$ & -23.73 & -30.43 & -37.70 & $\mathrm{Ni}<\mathrm{Si}<\mathrm{Ti}$ & $\mathrm{Ti}$ \\
\hline & $\mathrm{Ta}$ & -24.12 & -29.65 & -36.74 & $\mathrm{Ni}<\mathrm{Si}<\mathrm{Ti}$ & $\mathrm{Ti}$ \\
\hline \multirow{3}{*}{6} & $\mathrm{Cr}$ & -20.28 & -16.21 & -19.18 & $\mathrm{Si}<\mathrm{Ti}<\mathrm{Ni}$ & $\mathrm{Ni}$ \\
\hline & Mo & -18.59 & -17.21 & -20.05 & $\mathrm{Si}<\mathrm{Ni}<\mathrm{Ti}$ & $\mathrm{Ti}$ \\
\hline & $\mathrm{W}$ & -17.99 & -15.15 & -17.78 & $\mathrm{Si}<\mathrm{Ti}<\mathrm{Ni}$ & $\mathrm{Ni}$ \\
\hline \multirow{2}{*}{7} & $\mathrm{Mn}$ & -25.25 & -17.32 & -21.21 & $\mathrm{Si}<\mathrm{Ti}<\mathrm{Ni}$ & $\mathrm{Ni}$ \\
\hline & $\operatorname{Re}$ & -26.18 & -12.91 & -15.07 & $\mathrm{Si}<\mathrm{Ti}<\mathrm{Ni}$ & $\mathrm{Ni}$ \\
\hline 8 & Os & -34.05 & -14.28 & -15.76 & $\mathrm{Si}<\mathrm{Ti}<\mathrm{Ni}$ & $\mathrm{Ni}$ \\
\hline \multirow{2}{*}{9} & $\mathrm{Co}$ & -32.45 & -14.46 & -16.83 & $\mathrm{Si}<\mathrm{Ti}<\mathrm{Ni}$ & $\mathrm{Ni}$ \\
\hline & Ir & -38.57 & -17.73 & -17.81 & $\mathrm{Si}<\mathrm{Ti}<\mathrm{Ni}$ & $\mathrm{Ni}$ \\
\hline 10 & $\mathrm{Pt}$ & -46.09 & -21.74 & -21.21 & $\mathrm{Ti}<\mathrm{Si}<\mathrm{Ni}$ & $\mathrm{Ni}$ \\
\hline \multirow{2}{*}{11} & $\mathrm{Cu}$ & -15.29 & -12.22 & -14.57 & $\mathrm{Si}<\mathrm{Ti}<\mathrm{Ni}$ & $\mathrm{Ni}$ \\
\hline & $\mathrm{Au}$ & -25.74 & -11.92 & -12.43 & $\mathrm{Si}<\mathrm{Ti}<\mathrm{Ni}$ & $\mathrm{Ni}$ \\
\hline \multirow{2}{*}{13} & $\mathrm{Al}$ & -19.67 & -32.71 & -34.04 & $\mathrm{Ni}<\mathrm{Si}<\mathrm{Ti}$ & $\mathrm{Ti}$ \\
\hline & $\mathrm{Ga}$ & -16.40 & -30.91 & -30.62 & $\mathrm{Ni}<\mathrm{Ti}=\mathrm{Si}$ & $\mathrm{Si}$ or $\mathrm{Ti}$ \\
\hline 14 & $\mathrm{Ge}$ & -19.94 & -29.65 & -27.38 & $\mathrm{Ni}<\mathrm{Ti}<\mathrm{Si}$ & $\mathrm{Si}$ \\
\hline
\end{tabular}

The largest negative value among three types of calculated heats of formation is indicated by boldface. The symbols "Ni", "Si", and "Ti" in the column "Substitution site" mean that thequaternary element X substitutes for Ni atoms, Si atoms, and Ti atoms, respectively.

of quaternary elements $\mathrm{X}$ is systematic and therefore suggested to be primarily controlled by electronic (or chemical) nature denoted by the number in the periodic table. However, it should be noted in Table 2 and Fig. 2 that meaningful substitution behavior may be not specified when the difference in the heats of formation among three types of the substitutions or between two types of the substitutions is too small. 


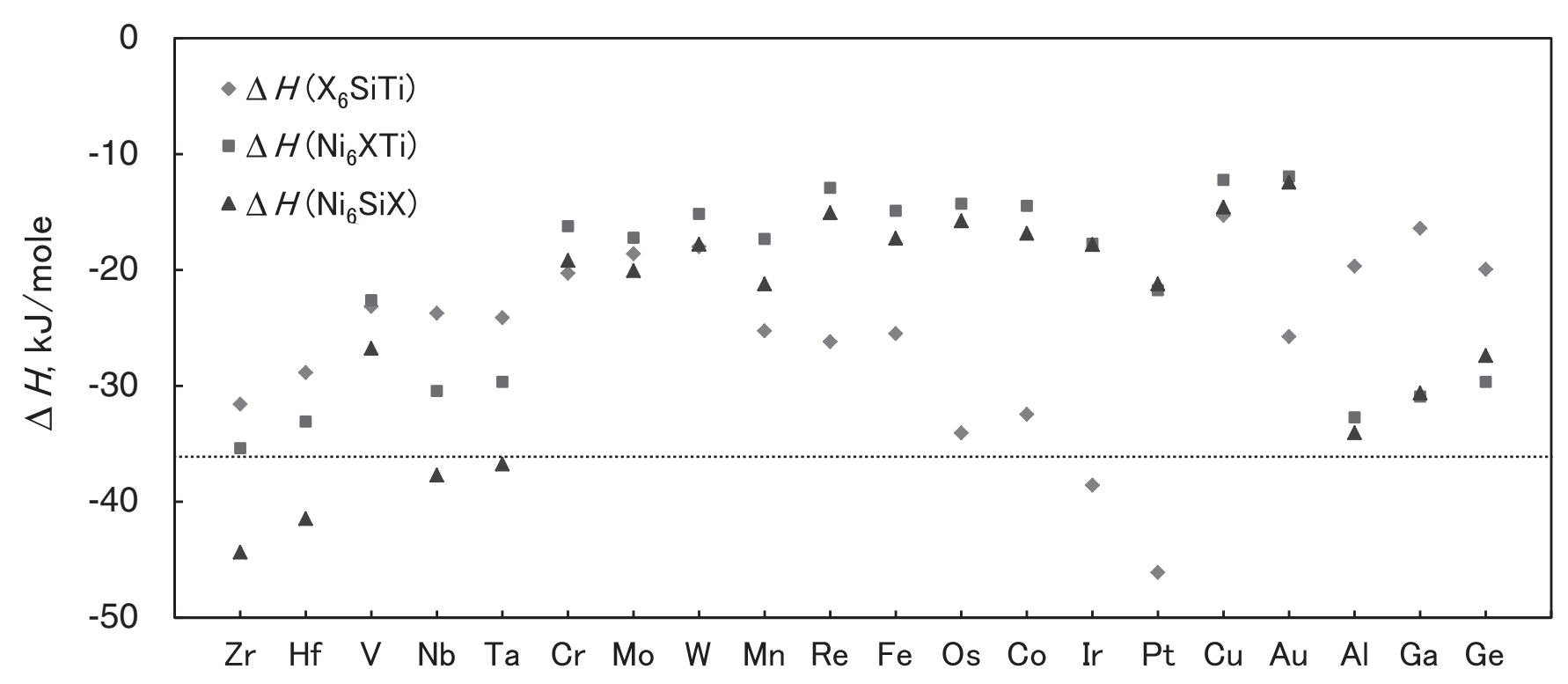

\section{Quaternary element}

Fig. 2 Three types of calculated heats of formation, $\Delta H\left(\mathrm{X}_{6} \mathrm{SiTi}\right), \Delta H\left(\mathrm{Ni}_{6} \mathrm{XTi}\right)$, and $\Delta H\left(\mathrm{Ni}_{6} \mathrm{SiX}\right)$. The horizontal dashed line indicates the value for the host compound, $\Delta H\left(\mathrm{Ni}_{6} \mathrm{SiTi}\right)=-36.02 \mathrm{~kJ} / \mathrm{mole}$ of atoms.

Figure 2 indicates that the calculated heats of formation for most of quaternary elements $\mathrm{X}$ are less negative than the heat of formation of the host compound, $\Delta H\left(\mathrm{Ni}_{6} \mathrm{SiTi}\right)=$ $-36.02 \mathrm{~kJ} / \mathrm{mole}$. Exception is the calculated heats of formation for $\Delta H\left(\mathrm{X}_{6} \mathrm{SiTi}\right)(\mathrm{X}=\mathrm{Pt}, \mathrm{Ir})$ and $\Delta H\left(\mathrm{Ni}_{6} \mathrm{SiX}\right)$ $(\mathrm{X}=\mathrm{Zr}$, Hf, $\mathrm{Nb}, \mathrm{Ta})$. Figure 3 plots relative heats of formation of $\Delta H\left(\mathrm{X}_{6} \mathrm{SiTi}\right)$ to $\Delta H\left(\mathrm{Ni}_{6} \mathrm{XTi}\right)$ (Fig. 3(a)), $\Delta H$ $\left(\mathrm{Ni}_{6} \mathrm{SiX}\right)$ to $\Delta H\left(\mathrm{Ni}_{6} \mathrm{XTi}\right)$ (Fig. 3(b)) and $\Delta H\left(\mathrm{X}_{6} \mathrm{SiTi}\right)$ to $\Delta H\left(\mathrm{Ni}_{6} \mathrm{SiX}\right)$ (Fig. 3(c)). The heats of formation of these ternary compounds were normalized by that of the host compound $\mathrm{Ni}_{6} \mathrm{SiTi}$. These calculated results shown in Figs. 2 and 3 reveal that a strong binding force between the constituent elements of $\mathrm{Ni}_{3}(\mathrm{Si}, \mathrm{Ti})$ with an inherently large negative heat of formation is reduced by the addition of most of the quaternary elements $\mathrm{X}$, and enhanced by the addition of $\mathrm{Ir}$ and $\mathrm{Pt}$ substituting for $\mathrm{Ni}$ atoms, and $\mathrm{Zr}, \mathrm{Hf}, \mathrm{Nb}$, and Ta substituting for $\mathrm{Ti}$ atoms.

In Fig. 3, the straight lines, whose slopes and intercepts are 1 and 0 respectively, bound quaternary elements $\mathrm{X}$ into two separate parts with regard to the site preference, the Si site or the Ni site (Fig. 3(a)), the Si site or the Ti site (Fig. 3(b)) and the Ti site or the Ni site (Fig. 3(c)). In Fig. 3(a), the elements $\mathrm{X}$ situated above the line are predicted to substitute for more $\mathrm{Si}$ atoms than $\mathrm{Ni}$ atoms, and those below the line are predicted to substitute for more $\mathrm{Ni}$ atoms than $\mathrm{Si}$ atoms and those just close to the line are predicted to substitute for an equal amount of Si and Ni atoms. In Fig. 3(b), the elements X situated above the line are predicted to substitute for more $\mathrm{Si}$ atoms than $\mathrm{Ti}$ atoms, and those below the line are predicted to substitute for more $\mathrm{Ti}$ atoms than $\mathrm{Si}$ atoms and those just close to the line are predicted to substitute for approximately equal amount of Si and Ti atoms. In Fig. 3(c), the elements X situated above the line are predicted to substitute for more $\mathrm{Ti}$ atoms than $\mathrm{Ni}$ atoms, and those below the line are predicted to substitute for more $\mathrm{Ni}$ atoms than $\mathrm{Ti}$ atoms and those just close to the line are predicted to substitute for approximately equal amount of $\mathrm{Ti}$ and $\mathrm{Ni}$ atoms.

The prediction for $\mathrm{Ta}$ is consistent with the reported experimental result; by $\mathrm{x}$-ray diffraction (XRD) and metallurgical observation, Ta has been shown to be preferentially substituted for the $\mathrm{Ti}$ sites rather than for the $\mathrm{Si}$ or Ni sites, and result in significant hardening. ${ }^{17)} \mathrm{We}$ compared the calculated results for $\mathrm{Ni}_{6} \mathrm{SiTi}$ to those for $\mathrm{Ni}_{3} \mathrm{Si}$ with $\mathrm{L1}_{2}$ structure. ${ }^{1)}$ In $\mathrm{Ni}_{6} \mathrm{SiTi}, \mathrm{Mn}$ (7), Co (9), and Pt (10) have the site preference for the face center (the $\mathrm{Ni}$ site) and $\mathrm{V}, \mathrm{Nb}$, and $\mathrm{Ta}$ (5), Mo (6), Al and Ga (13), and Ge (14) for the cube corner (the $\mathrm{Si}$ site or the Ti site). This result is similar to that in $\mathrm{Ni}_{3} \mathrm{Si}$, in which $\mathrm{Mn}$ (7), Co (9), and $\mathrm{Pt}$ (10) prefer the face center (the $\mathrm{Ni}$ site) and $\mathrm{V}, \mathrm{Nb}$, and $\mathrm{Ta}$ (5), Mo (6), $\mathrm{Al}$ and $\mathrm{Ga}(13)$, and $\mathrm{Ge}(14)$ prefer the cube corner (the Si site). ${ }^{1)}$

Discussing the reliability of the present calculation predicting the substitution of a quaternary element $\mathrm{X}$, much more experimental date should be collected. Also, the present calculation should be compared with the ab initio calculation or the thermodynamic calculations in which the entropy (i.e., temperature) effect was taken into.

\section{The Solubility Limits of Quaternary Elements}

For the solubility limits of ternary elements $\mathrm{X}$ in $\mathrm{Ni}_{3} \mathrm{Al}$ and $\mathrm{Ni}_{3} \mathrm{Ga}$ with $\mathrm{L}_{2}$ structure, Ochiai et al. found a successful prediction on the two-dimensional map, which was characterized by two parameters, i.e. the difference in heats of formation between $\mathrm{Ni}_{3} \mathrm{Al}$ (or $\mathrm{Ni}_{3} \mathrm{Ga}$ ) and $\mathrm{Ni}_{3} \mathrm{X}$, and the changing rate of lattice parameter by ternary element $\mathrm{X}$ of $\mathrm{Ni}_{3} \mathrm{Al}$ (or $\mathrm{Ni}_{3} \mathrm{Ga}$ ). ${ }^{1)}$ To apply this prediction to $\mathrm{Ni}_{3}(\mathrm{Si}, \mathrm{Ti}$ ), a couple of assumptions should be given. The first 


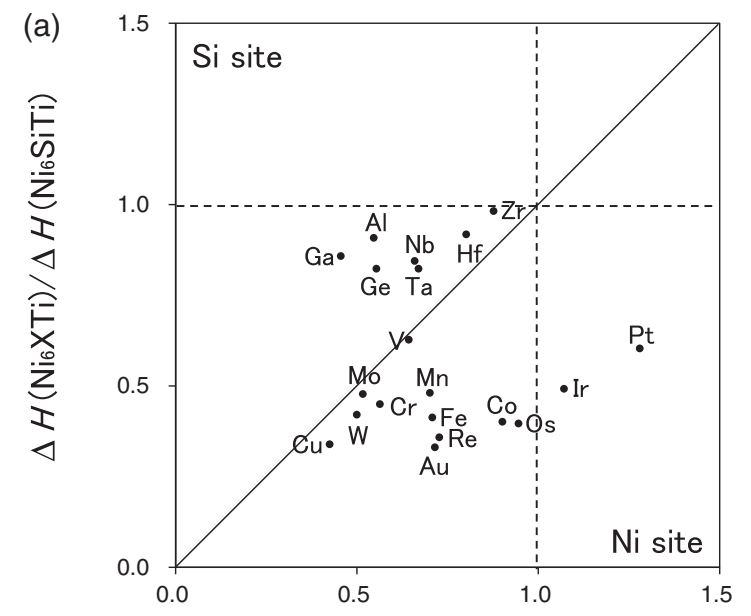

$\Delta H\left(\mathrm{X}_{6} \mathrm{SiTi}\right) / \Delta H\left(\mathrm{Ni}_{6} \mathrm{SiTi}\right)$

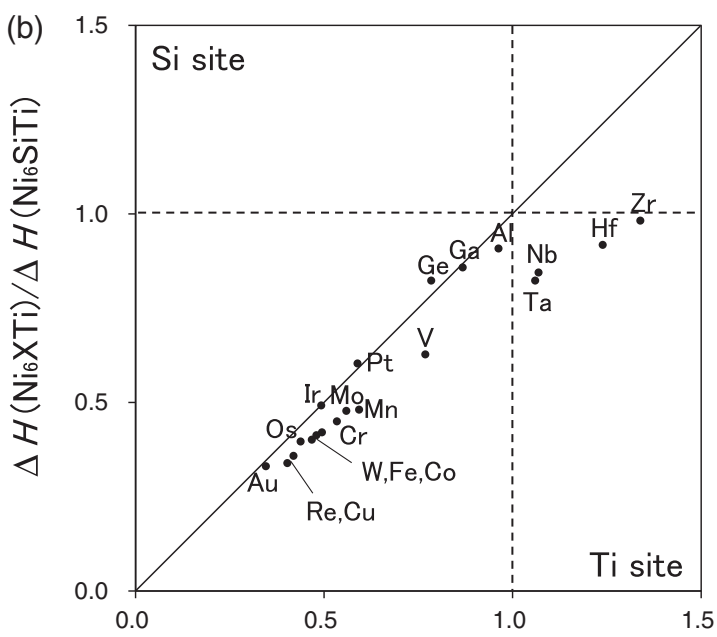

$\Delta H\left(\mathrm{Ni}_{6} \mathrm{SiX}\right) / \Delta H\left(\mathrm{Ni}_{6} \mathrm{SiTi}\right)$

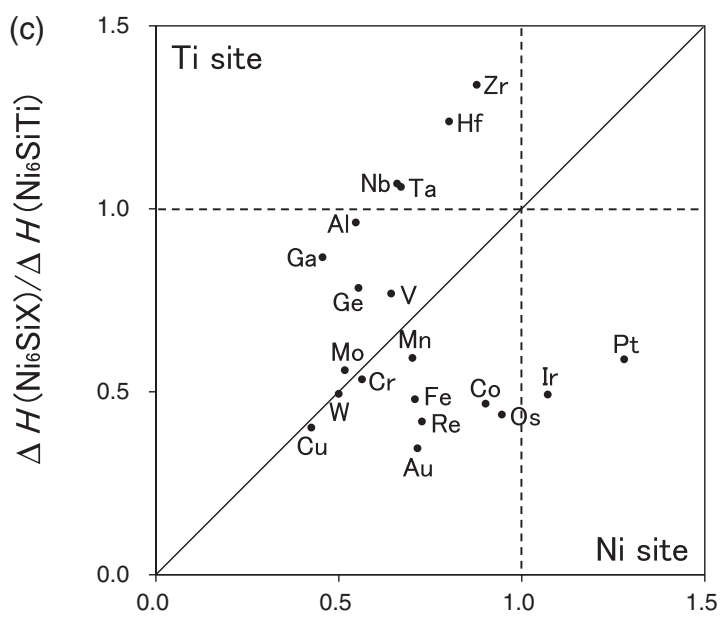

$\Delta H\left(\mathrm{X}_{6} \mathrm{SiTi}\right) / \Delta H\left(\mathrm{Ni}_{6} \mathrm{SiTi}\right)$

Fig. 3 (a) $\Delta H\left(\mathrm{X}_{6} \mathrm{SiTi}\right)$ vs. $\Delta H\left(\mathrm{Ni}_{6} \mathrm{XTi}\right)$ plots, (b) $\Delta H\left(\mathrm{Ni}_{6} \mathrm{SiX}\right)$ vs. $\Delta H$ $\left(\mathrm{Ni}_{6} \mathrm{XTi}\right)$ plots and (c) $\Delta H\left(\mathrm{X}_{6} \mathrm{SiTi}\right)$ vs. $\Delta H\left(\mathrm{Ni}_{6} \mathrm{SiX}\right)$ plots. The heats of formation of quaternary compounds were normalized by that of the host compound $\mathrm{Ni}_{6} \mathrm{SiTi}$.

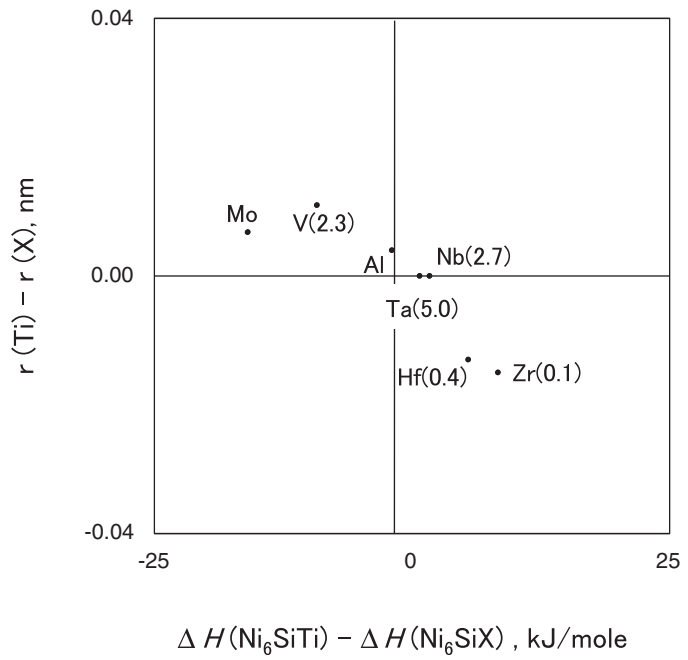

Fig. 4 The difference between the heats of formation of $\mathrm{Ni}_{6} \mathrm{SiTi}$ and $\mathrm{Ni}_{6} \mathrm{SiX}$ vs. the size difference between $\mathrm{Ti}$ and the quaternary element $\mathrm{X}$. The numerical values expressed in the parentheses mean the experimental solubility limits (at\%) of quaternary elements $\mathrm{X}$ for the $\mathrm{Ti}$ site in $\mathrm{Ni}_{3}(\mathrm{Si}, \mathrm{Ti})$.

assumption, which is the same as that taken in the previous section, is that the $\mathrm{Ni}_{3}(\mathrm{Si}, \mathrm{Ti})$ compound is regarded as the perfectly ordered $\mathrm{Ni}_{6} \mathrm{SiTi}$ compound. The second assumption is that the calculation will be done only when quaternary elements $\mathrm{X}$ substitute for $\mathrm{Ti}$ atoms because such a substitution way is expected to result in some beneficial effects, e.g., improvement of the oxidation and corrosion resistance and high-temperature mechanical properties of $\mathrm{Ni}_{3}(\mathrm{Si}, \mathrm{Ti})$. Theoretical calculations mentioned above have shown in the previous section that $\mathrm{Zr}$ and $\mathrm{Hf}$ (4), $\mathrm{V}, \mathrm{Nb}$, and $\mathrm{Ta}$ (5), Mo (6), and $\mathrm{Al}$ (13) substitute for $\mathrm{Ti}$ atoms in $\mathrm{Ni}_{6} \mathrm{SiTi}$.

Figure 4 represents a plot of the difference between heats of formation of $\mathrm{Ni}_{6} \mathrm{SiTi}$ and $\mathrm{Ni}_{6} \mathrm{SiX}$ vs. the atomic size difference between $\mathrm{Ti}$ and the quaternary element $\mathrm{X}$. In this analysis, the changing rate of lattice parameter by the quaternary element of $\mathrm{Ni}_{3}(\mathrm{Si}, \mathrm{Ti})$ was replaced by the atomic size difference between $\mathrm{Ti}$ and the quaternary element $\mathrm{X}$ because no data are available for the changing rate of lattice parameter by the quaternary element of $\mathrm{Ni}_{3}(\mathrm{Si}, \mathrm{Ti})$. Also, heats of formation of $\mathrm{Ni}_{6} \mathrm{SiTi}$ and $\mathrm{Ni}_{6} \mathrm{SiX}$ were again calculated using a geometric model based on extended Miedema's theories. ${ }^{22-24)}$ Here, it is implicitly supposed that the maximum solubility for the $\mathrm{Ti}$ site is expected in quaternary elements $\mathrm{X}$ with which data points lie near the origin. The experimental data points for Ta $(5.0 \mathrm{at} \%)^{17)}$ and $\mathrm{Nb}(2.7 \mathrm{at} \%)^{13)}$ which showed relatively large solid solubilities in $\mathrm{Ni}_{3}(\mathrm{Si}$, Ti) lay near the origin of the orthogonal coordinate. On the other hand, the experimental data points for $\mathrm{Zr}(0.1 \mathrm{at} \%)^{13)}$ and $\mathrm{Hf}(0.4 \mathrm{at} \%)^{13)}$ that showed small solid solubilities in $\mathrm{Ni}_{3}(\mathrm{Si}, \mathrm{Ti})$ lay on the positions far from the origin. Therefore, in $\mathrm{Ni}_{3}(\mathrm{Si}, \mathrm{Ti})$, it is concluded that the solubility limits of quaternary elements $\mathrm{X}$ for the Ti site are dominated by two parameters: (1) the difference between the heats of compound formation of $\mathrm{Ni}_{6} \mathrm{SiTi}$ and $\mathrm{Ni}_{6} \mathrm{SiX}$; and (2) the atomic size difference between $\mathrm{Ti}$ and the quaternary element $\mathrm{X}$. In other words, 
Ochiai et al.'s prediction well explains the solubility limits of quaternary elements $\mathrm{X}$ in $\mathrm{Ni}_{3}(\mathrm{Si}, \mathrm{Ti}){ }^{1)}$ It is expected that the solubility limits of quaternary elements $\mathrm{X}$ for the Ni site and for the $\mathrm{Si}$ site can hold the same trend as for the $\mathrm{Ti}$ site in view of the result shown in Fig. 4. Unfortunately, there are no experimental data in such two cases whether the prediction based on these two parameters is applicable or not.

\section{Conclusion}

The alloying behavior of various kinds of quaternary elements $\mathrm{X}$ in $\mathrm{Ni}_{3}(\mathrm{Si}, \mathrm{Ti})$ was predicted by assuming a $\mathrm{Ni}_{6} \mathrm{SiTi}$ compound and by using the thermodynamics based on an extended Miedema's equation. The following conclusion was obtained from the present study.

(1) The heats of formation of the ternary compounds reported in $\mathrm{Ni}-\mathrm{Si}-\mathrm{Ti}, \mathrm{X}-\mathrm{Si}-\mathrm{Ti}$, and $\mathrm{Ni}-\mathrm{Si}-\mathrm{X}$ alloy systems where $\mathrm{X}$ is the quaternary element were calculated and shown to agree well with experimental values and other eletronical calculations.

(2) From the thermodynamic treatment adopted, $\mathrm{Cr}$ and $\mathrm{W}$ (6), Mn and Re (7), Fe and Os (8), Co and Ir (9), Pt (10), and $\mathrm{Cu}$ and $\mathrm{Au}(11)$ were predicted to substitute for $\mathrm{Ni}$ atoms. $\mathrm{Ge}(14)$ was predicted to substitute for $\mathrm{Si}$ atoms. $\mathrm{Zr}$ and $\mathrm{Hf}$ (4), V, Nb, and Ta (5), Mo (6), and Al (13) were predicted to substitute for Ti atoms. Ga (13) was predicted to substitute for $\mathrm{Si}$ or $\mathrm{Ti}$ atom. The prediction for Ta was consistent with the reported experimental result.

(3) It was demonstrated from the present thermodynamic argument that a strong binding force between the constituent elements comprising of $\mathrm{Ni}_{3}(\mathrm{Si}, \mathrm{Ti})$ is often reduced by the addition of the majority of quaternary elements X.

(4) It was shown that the solubility limits of quaternary elements $\mathrm{X}$ for the $\mathrm{Ti}$ site in $\mathrm{Ni}_{3}(\mathrm{Si}, \mathrm{Ti})$ were correlated with the size misfit parameter between $\mathrm{Ti}$ and the quaternary element $\mathrm{X}$, and the difference in the heats of formation between $\mathrm{Ni}_{6} \mathrm{SiTi}$ and $\mathrm{Ni}_{6} \mathrm{SiX}$.

\section{Acknowledgements}

This work was supported in part by Grant-in-aid for Scientific Research for the Ministry of Education, Culture, Sports, Science and Technology, Japan.

\section{REFERENCES}

1) S. Ochiai, Y. Oya and T. Suzuki: Acta Metall. 32 (1984) 289-298.

2) A. R. Miedema, R. Boom and F. R. de Boer: Crystal Structure and Chemical Bonding in Inorganic Chemistry, (American Elsevier, NorthHolland, 1975) p. 163.

3) A. R. Miedema and P. F. du Chatel: Theory of Alloy Phase Formation, (Metall. Soc. A.I.M.E, 1980) p. 334.

4) Y. Liu, T. Takasugi and O. Izumi: Metall. Trans. A 17 (1986) 14331439.

5) H. Sugimura, Y. Kaneno and T. Takasugi: Mater. Trans. 51 (2010) 7277.

6) H. Sugimura, Y. Kaneno and T. Takasugi: J. Alloy. Compd. 496 (2010) 116-121.

7) H. Sugimura, Y. Kaneno and T. Takasugi: Mater. Sci. Forum 654-656 (2010) 440-443.

8) H. Sugimura, Y. Kaneno and T. Takasugi: MRS Symp. Proc. 1295 (2011) N05-27.

9) H. Sugimura, Y. Kaneno and T. Takasugi: Mater. Trans. 52 (2011) 663-671.

10) T. Takasugi, M. Nagashima and O. Izumi: Acta Metall. Mater. 38 (1990) 745-755

11) T. Takasugi, D. Shindo, O. Izumi and M. Hirabayashi: Acta Metall. Mater. 38 (1990) 739-745.

12) Y. Kaneno, T. Myoki and T. Takasugi: Int. J. Mat. Res. 99 (2008) 1229-1236.

13) T. Takasugi: Intermetallics 8 (2000) 575-584.

14) Y. Fujimoto, Y. Kaneno and T. Takasugi: MRS Symp. Proc. 1128 (2009) 245-250.

15) Y. Fujimoto, Y. Kaneno, M. Yoshida and T. Takasugi: Mater. Sci. Eng. A 528 (2011) 4104-4110.

16) A. Kai, D. Imajo, Y. Kaneno and T. Takasugi: Mater. Sci. Forum 654656 (2010) 472-475.

17) D. Imajo, Y. Kaneno and T. Takasugi: MRS Symp. Proc. 1295 (2011) N05-22.

18) P. A. Flinn: Trans. Met. Soc. AIME 218 (1960) 145-154.

19) T. Takasugi, S. Watanabe, O. Izumi and N. K. Fat-Halla: Acta Metall. 37 (1989) 3425-3436.

20) A. K. Das, R. Nakamura, M. Takahashi, H. Iwasaki, T. Shishido and K. Ohshima: J. Phys. Soc. Jpn. 75 (2006) 024604-1-024604-6.

21) Y. Ouyang, X. Zhong, Y. Du, Z. Jin, Y. He and Z. Yuan: J. Alloy. Compd. 416 (2006) 148-154.

22) Y. Ouyang, X. Zhong, Y. Du, Y. Feng and Y. He: J. Alloy. Compd. 420 (2006) 175-181.

23) Y. Du, J. Wang, Y. F. Ouyang, L. J. Zhang, Z. H. Yuan, S. H. Liu and P. Nash: J. Min. Metall. 46 (2010) 1-9.

24) T. Tokunaga, K. Hashima, H. Ohtani and M. Hasebe: Mater. Trans. 45 (2004) 1507-1514

25) A. Grytsiva, X. Q. Chen, P. Rogla, R. Podloucky, H. Schmidt, G. Giester and V. Pomjakushin: J. Solid State Chem. 180 (2007) 733-741.

26) X. L. Yan, X. Q. Chen, A. Grytsiv, V. T. Witusiewicz, P. Rogl, R. Podloucky and G. Giester: J. Alloy. Compd. 429 (2007) 10-18.

27) W. Xiong, Y. Du, J. Wang, W. W. Zhang and X. G. Lu: Int. J. Mater. Res. 99 (2008) 598-612. 